\title{
In vitro propagation of Nanorrhinum ramosissimum (Wall.) Betsche: A traditionally important medicinal plant
}

\author{
Jyotsna Sharma, Anuja Koul, Savita Sharma, Raju Shankarayan, Sharada Mallubhotla* \\ School of Biotechnology, Faculty of Sciences, Shri Mata Vaishno Devi University, Katra - \\ 182320, J\&K, India \\ *Corresponding author: sharda.p@smvdu.ac.in
}

\begin{abstract}
An efficient micropropagation protocol facilitates successful conservation and improvement of Nanorrhinum ramosissimum (Wall.) Betsche by biotechnological means. Shoot tip explants exhibited optimal organogenic response when inoculated on half-strength(1/2) Murashige and Skoog (MS) medium supplemented with kinetin (KN) and indole-3-acetic acid (IAA) $(0.5 \mathrm{mg} / \mathrm{L}$ each). Shoot organogenesis was further enhanced when the multiplication medium was fortified with dextrose (1\%) (2.6 shoots/explant; $7.9 \mathrm{~cm}$ shoot length). The regenerated shoots formed roots; however, the best rooting frequency $(87 \%)$ was achieved on half-strength MS medium containing only IAA $(0.5 \mathrm{mg} / \mathrm{L})$. Four-week-old in vitro plantlets were acclimatized with $95 \%$ survival under greenhouse conditions. The regeneration protocol developed in this study can be utilized for germplasm conservation of this elite traditional medicinal plant.
\end{abstract}

Keywords: Acclimatization; carbon sources; micropropagation; plant growth regulators;plant regeneration.

\section{Introduction}

Successful biotechnological approaches such as plant genetic engineering and phenotypic screening eventually rely on the potential to regenerate the whole plant system efficiently using tissue culture techniques. The rapid and direct regeneration system protocol is most preferred where the intermediate callusing stage is surpassed and production of multiple shoots occurs. Nanorrhinum ramosissimum (Wall.) Betsche (accepted name of the species in the genus Nanorrhinum) belongs to the family Plantaginaceae having common synonyms Kickxia ramosissima (Wall.) Janchen, Linaria ramosissima Wall, and Elatinoides ramosissima (Walter) Kuntze (The Plant List, 2020). The plant habituates stone crevices and attains a length of $40 \mathrm{~cm}$ with lobed or triangular-shaped leaves. In India, it is commonly known as Khunger booti (Hindi), Kanodi or Bhintgalodi (Gujarati), Banwel (Marathi), (Pullaiah \& Naidu, 2003; Kritikar \& Basu, 2005; Pandya et al., 2013; Flowers of India, 2020).
The whole plant is reported to be medicinally important. It has been traditionally used as a remedy for diabetes and extensively accredited in ancient medicinal literature for the treatment of various other diseases like rheumatism, jaundice, and as an immune system activator (Bhandari, 2006, Ahmad et al., 2009; Jan and Khan, 2016; Amin et al., 2017).Despite possessing such important properties, the potential of this herb is not yet fully explored or included in the present health care regime due to the limited availability of plant material for research purposes. The main constraint in its availability is its habitat specificity, which is mainly found growing in crevices. Unlike other medicinal plants, it is impossible to commercially cultivate the herb in field beds easily (Pullaiah \& Naidu, 2003; Kritikar \& Basu, 2005). Therefore, to fulfill the scarce availability of plant material, the overall objective of this study was to develop an efficient protocol by evaluating the effect of 
different media components.

\section{Methodology}

\subsection{Collection of plant material}

Twigs of $N$. ramosissimum bearing active shoot tips in the growing season (AprilOctober, 2015) were used as explants, collected from its natural habitat at Akhnoor, Jammu District, Jammu \& Kashmir, India (Figure 2a) and identified by Sh. O.P Sharma, IFS, Director, Department of Environment, Ecology and Remote Sensing, J\&K, India. A specimen of the plant is deposited at Janaki Ammal Herbarium, CSIR-Indian Institute of Integrative Medicine (CSIR-IIIM), Jammu, J\&K, with Accession No. RRLH23493.

\subsubsection{Surface disinfection of the explants}

The shoot tip explants (1-2 cm length) were thoroughly washed with tap water and $2 \%$ detergent (Tween 20; v/v) to remove superficial contaminants. Excised shoot tips $(0.5-1.0 \mathrm{~cm})$ were then subjected to primary treatment with sodium hypochlorite $(1 \%$; $\mathrm{v} / \mathrm{v})$ for 3 minutes and kept under running tap water for one hr. Further sterilization was carried out by aseptically treating the explants with mercuric chloride $(0.2 \%$; w/v) for $2 \mathrm{~min}$, followed by washing with sterile double distilled water 3-4 times.

\subsubsection{Media optimization and culture conditions}

Explants were blotted on sterile filter paper and cultured on different basal plant growth media, i.e., Murashige and Skoog (MS) (Murashige \& Skoog, 1962), Whites medium (WH) (White, 1963), and Gamborg's medium (B5) (Gamborg et al., 1976) to establish in vitro shoot cultures. Established shoot tips regenerated in vitro (as above) ( 8 weeks old) were further inoculated on MS medium of differing strengths, i.e., full, half, and quarter, and in combination with different plant growth regulators (PGRs)
[Kinetin (KN), Benzyl amino purine (BAP), Indole-3-acetic acid (IAA)] singly and in combination at a concentration of $0.5 \mathrm{mg} / \mathrm{L}$ to study their influence on shoot regeneration. Table sugar at $3 \%(\mathrm{w} / \mathrm{v})$ as the carbon source and agar at $0.7 \%(\mathrm{w} / \mathrm{v})$ as a gelling agent were used uniformly unless otherwise specified. The $\mathrm{pH}$ of all media was adjusted to $5.8 \pm 0.2$. Explants were incubated under controlled growth room conditions provided with 2000 lux/m3 light intensity using cool white fluorescent LED bulbs (Philips, India), a temperature of $25 \pm 2{ }^{\circ} \mathrm{C}$, and a photoperiod $16 / 8$ hours. Sub-culturing was performed after 4 weeks onto a fresh medium of the original composition.

2.1.3. Effect of different carbon sources and their concentration on shoot multiplication of $N$. ramosissimum

To check the effect of dissimilar sources of carbon on shoot multiplication, in vitro regenerated shoots $(1.5-2.0 \mathrm{~cm})$ were inoculated on the best suitable medium observed as above (2.1.2) containing varying concentrations and types of carbon sources viz. table sugar, fructose, sucrose, maltose, and dextrose at a concentration of 1,3 and $5 \%(\mathrm{w} / \mathrm{v})$.

\subsubsection{In vitro root induction}

In vitro regenerated shoot clusters $(2-3 \mathrm{~cm}$ length; 6 shoots/cluster) regenerated on optimal multiplication medium (2.1.3) were excised and inoculated onto half-strength MS medium containing auxins [IAA/IBA (Indole-3-butyric acid) in a concentration range of 0.5-3.0 $\mathrm{mg} / \mathrm{L})$ ]. Culture conditions were maintained throughout the experiment as described previously. After four weeks, several roots, mean root length, and rooting percentage, per explant were recorded.

2.1.5. Hardening and pot establishment of the regenerated plantlets

Rooted plantlets were carefully removed 
from culture tubes, washed to remove adhering agar, and transferred to perforated plastic cups containing sterile sand/soil mixture (1:1) for hardening. The plantlets were incubated in a plant growth chamber (Spire Automation and Innovation, India) at ambient temperature $\left(25 \pm 2{ }^{\circ} \mathrm{C}\right)$ and humidity (70-80\%) under a 16/8 $\mathrm{h}$ photoperiod regime, where the light intensity was increased progressively from 2000, 3000, 4000 lux/ $\mathrm{m} 3$ after one week each to acclimatize the plantlets to the exvitro environment. The cups containing plantlets were enclosed with clear polythene bags to keep them saturated with moisture and were steadily periodically perforated ( 5 perforations of $2 \mathrm{~mm}$ diameter/ alternate day). Survival rate and growth parameters (plantlet length, mean leaf number) were recorded upto three weeks of acclimatization and monitored similarly for upto four weeks after transfer to field bed conditions.

\section{Observations and data analysis}

Experimental data recorded in triplicates (six explants/treatment) is expressed by their mean values and standard deviation (SD). ANOVA (one-way analysis of variance) was performed (SPSS software version 17.0) and the significance of difference analyzed by Duncan's multiple range test (DMRT).

$\mathrm{P}$ value $\leq 0.05$ was considered to be statistically significant.

\section{Results and discussion}

4.1. Effect of different media and medium strength on culture initiation

Among the three different media used, optimal growth was observed on MS basal medium in terms of leaf number [16.6(0.39)], shoot number [2.55(0.14)] and shoot length (cm) $[3.7(0.15)]$ followed by that in B5 and White's media. (Table 1; Figure 1ac.). Among the three different media used, optimal growth was observed on MS basal medium in terms of leaf number [16.6(0.39)], shoot number $[2.55(0.14)]$ and shoot length (cm) [3.7(0.15)] followed by that in B5 and White's media. (Table 1; Figure 1a-c.). The effect of medium strength indicates that the highest rate of shoot multiplication was observed on half-strength (1/2) MS medium in terms of leaf number [26.3(0.22)], shoot number $[1.7(0.5)]$, and shoot length $(\mathrm{cm})$ [7.5(0.12)] (Table 2; Figure 1d.) followed by quarter and full-strength MS medium, signifying that the plant probably does not have a high mineral nutrient requirement. Nutritional needs for an ideal in vitro growth and plant regeneration are speciesdependent. Likewise, different tissues from different plant parts may have diverse requirements for their patterns of growth and organogenesis (Murashige \& Skoog, 1962). Therefore, a single medium cannot be suited for all types of plants, tissues, or organs of plants. Thus, during culture induction or regeneration experiments in a new plant species, it is obligatory to standardize a medium that can fulfill its specific nutritional requirements (Bhojwani \& Razdan, 1996). Several reports are in concordance with our study where shoot induction has been successfully achieved by culturing shoot tips (Mallubhotla et al., 2008; Babaei et al., 2014; Mohamed et al., 2019).

\subsection{Effect of different plant growth regulators on shoot proliferation}

The highest shoot proliferation in $N$. ramosissimum was observed on halfstrength (1/2) MS medium supplemented with a combination of $\mathrm{KN}$ and IAA (0.5 $\mathrm{mg} / \mathrm{L}$ each) (Table 3; Figure 2b.). Plant growth regulators have a noteworthy role in initializing a precise manner of regeneration in cultured plant cells and tissues that might be attributed to the accretion of specific biochemicals inthem (Gaspar et al.,1996). Anamalgamation of dissimilar growth hormones in the medium causes maintenance and more overbalances of the specific nutrient contents (inorganic/ organic) in the growing tissues, promoting 
Table 1. Effect of different media on shoot regeneration in N. ramosissimum.

\begin{tabular}{|c|c|c|c|}
\hline \multirow{2}{*}{$\begin{array}{l}\text { Medium } \\
\text { shoot }\end{array}$} & Mean leaf & Mean shoot & Mean \\
\hline & $\begin{array}{c}\text { number } \\
\text { (SD) }\end{array}$ & $\begin{array}{l}\text { number } \\
\text { (SD) }\end{array}$ & $\begin{array}{r}\text { length } \\
(\mathrm{cm})(\mathrm{SD})\end{array}$ \\
\hline MS & $16.6^{\mathrm{a}}(0.39)$ & $2.55^{\mathrm{a}}(0.14)$ & $3.7 \mathrm{a}(0.15)$ \\
\hline White's & $5.05^{\mathrm{c}}(0.26)$ & $1 \circ(0)$ & $1.6^{\mathrm{c}}(0.04)$ \\
\hline Gamborg's & $8 b(0.24)$ & $1.61 b(0.11)$ & $1.8 \mathrm{~b}(0.05)$ \\
\hline
\end{tabular}

Means followed by a different superscript in each column are significantly $(p<0.05)$ different from each other using DMRT. Numbers in brackets indicate standard deviation (SD).

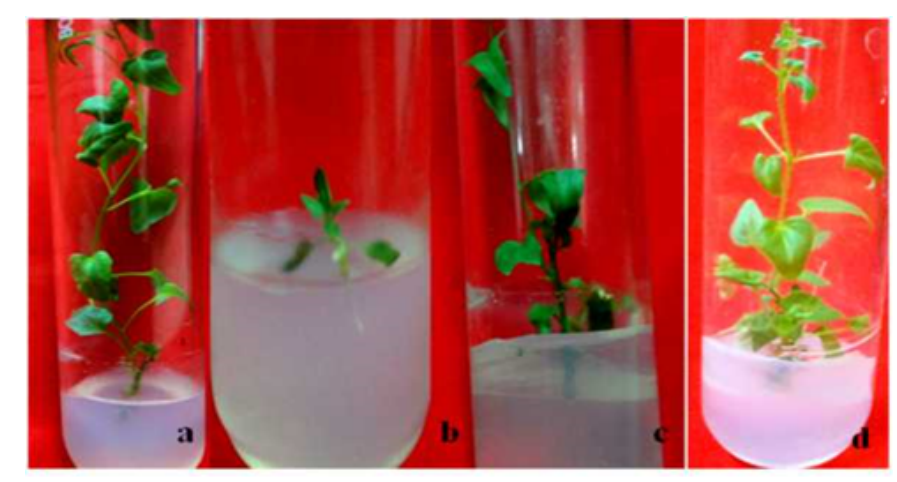

Fig. 1. Effect of different media on culture establishment from shoot explants of N. ramosissimum: (a) MS medium, (b) White's medium, (c) Gamborg's medium, (d) Half-strength (1/2) MS medium.

Table 2. Effect of MS medium strength on shoot multiplication in N. ramosissimum.

\begin{tabular}{|c|c|c|c|}
\hline $\begin{array}{l}\text { Medium } \\
\text { Strength }\end{array}$ & $\begin{array}{c}\text { Mean leaf } \\
\text { number } \\
\text { (SD) }\end{array}$ & $\begin{array}{l}\text { Mean shoot } \\
\text { number } \\
\text { (SD) }\end{array}$ & $\begin{array}{c}\text { Mean shoot } \\
\text { length } \\
\text { (cm) JSD) }\end{array}$ \\
\hline Full 1 & $15.4^{\mathrm{c}}(0.36)$ & 5) $\quad 1.0^{\mathrm{b}}(0)$ & $3.8^{\mathrm{c}}(0.16)$ \\
\hline Half & $26.3^{\mathrm{a}}(0.22)$ & $1.7^{\mathrm{a}}(0.15)$ & $7.5^{\mathrm{a}}(0.12)$ \\
\hline Quarter & $17.5^{\mathrm{b}}(0.20)$ & $1.0^{\mathrm{b}}(0)$ & $5.0^{\mathrm{b}}(0.17)$ \\
\hline
\end{tabular}

Means followed by a different superscript in each column are significantly $(P<0.05)$ different from each other using DMRT. Numbers in brackets indicate standard deviation (SD). 
cultures to grow into shoots/roots depending upon the stimulus applied (Madhulatha et al., 2004). Growth regulators were presently used in varied combinations to break dormancy and alleviate processes of shoot bud instigation. Auxins and cytokinins are of utmost magnitude in the course of in vitro regeneration, where the former is primarily required in the media for root induction and later for shoot regeneration (Dixon \& Gonzales, 1994; North et al., 2012). Various researchers have reported the synergistic effect of cytokinins and auxins in the process of shoot formation (Mallubhotla et al., 2008; Ngomuo et al., 2013). On comparing the physiological response obtained from the treatment of different cytokinins on shoot proliferation, it is indicative that $\mathrm{KN}$ was better suited over BAP, which produced a two-fold increase in shoot number. Similar results have also been reported for cucumber where $\mathrm{KN}$ proved to have better regenerability than BAP (Abu-Romman et al., 2015).

4.3.Effect of diverse carbon sources and their concentration on in vitro shoot multiplication of $N$. ramosissimum

Data obtained reveals that shoots induced on half-strength MS medium containing $\mathrm{KN}$ and $\mathrm{BAP}(0.5 \mathrm{mg} / \mathrm{L}$ each $)$ fortified with dextrose $(1 \% ; \mathrm{w} / \mathrm{v})$ resulted in maximum growth in terms of several leaves, shoots, and shoot length [26.05 (0.93), $2.6(0.48)$, $7.9(0.06)(\mathrm{cm})$ respectively], as compared to other carbon sources tested (Table 4). The next best carbon source which exhibited a positive influence was table sugar $(3 \% \mathrm{w} / \mathrm{v})$ in terms of the number of leaves, shoots, and shoot length [19.38 (1.8), 1.38 (0.50), [5.34 $(0.08)(\mathrm{cm})$ respectively] followed by sucrose and fructose at a concentration of $1 \%(\mathrm{w} / \mathrm{v})$. The treatment with maltose and dextrose $(5 \% ; \mathrm{w} / \mathrm{v})$ proved detrimental to shoot growth with pale yellow leaves. In the life cycle of a plant beginning from thevegetative phase to reproductive growth, processes (Thomson \& Thorpe, 1987). The sugars perform a crucial function in signaling prominent role of sugars in managing the response of varied plant genes and their association to metabolic and other growth processes has been elaborated (Koch, 1996). Hence, the growth and enhancement of in vitro shoots are a consequence of numerous aspects, including the kind andconcentration of exogenous carbon source added to the culture medium (Neto \& Otoni, 2003). Jain et al., 2008, also reported a direct association between medium strength and the number andlength of shoots induced in Harpagophytum procumbens. (Tetsumura et al., 2008), reported that a reduction in the MS medium strength resulted in increased in vitro shoot and root formation in Vaccinium corymbosu and $V$. virgatum.

\subsection{In vitro rooting, hardening, and pot establishment}

In the present study, all the treatments tested induced in vitro rooting and the best combination comprised of half-strength MS medium fortified with IAA $(0.5 \mathrm{mg} / \mathrm{L})$ (Table 5; Figure 2c-d.). Similar results have been reported in previous studies where IAA was superior to other auxins for rooting in plants such as Hedeoma multiflorum and Cardiospermum halicacabum (Overvoorde et al., 2010). Rooting of in vitro shoots area prerequisite for accomplishing a regeneration process as root development enhances the chances of accomplishing transplantation since functional roots can generate a good plant-water balance (Diaz-Perez et al., 1995). Shekhawat et al.,2015, also reported that auxins occupy an imperative task in initiating roots from in vitro raised shoots of Passiflora foetida. Similarly, rooting in Vaccinium corymbosu has reported the results which are in concordance with our study where the highest rooting percentage has been observed on half-strength $(1 / 2)$ medium fortified with auxins (Tetsumura et al., 2008). Reducing the MS medium strength to half resulted in better rooting of Mentha 
Table 3. Effect of plant growth regulators on shoot proliferation in N. ramosissimum.

\begin{tabular}{|lccc|}
\hline Treatment & $\begin{array}{c}\text { Mean leaf } \\
\text { number }\end{array}$ & $\begin{array}{c}\text { Mean shoot } \\
\text { number }\end{array}$ & $\begin{array}{c}\text { Mean shoot } \\
\text { length } \\
(\mathrm{cm})(\mathrm{SD})\end{array}$ \\
$1 / 2 \mathrm{MS}$ & $19.7 \mathrm{~b}(0.87)$ & $1.4 \mathrm{~b}(0.51)$ & $5.26 \mathrm{~b}(0.20)$ \\
$1 / 2 \mathrm{MS}+\mathrm{BAP}(0.5 \mathrm{mg} / \mathrm{L})$ & $11.5 \mathrm{~h}(0.61)$ & $1.05(0.23)$ & $3.33 \mathrm{f}(0.59)$ \\
$1 / 2 \mathrm{MS}+\mathrm{IAA}(0.5 \mathrm{mg} / \mathrm{L})$ & $12.3 \mathrm{~g}(0.48)$ & $1.0 \mathrm{c}(0)$ & $3.29 \mathrm{f}(0.11)$ \\
$1 / 2 \mathrm{MS}+\mathrm{KN}(0.5 \mathrm{mg} / \mathrm{L})$ & $14.2 \mathrm{e}(0.54)$ & $1.0 \mathrm{c}(0)$ & $3.9 \mathrm{~d}(0.07)$ \\
$1 / 2 \mathrm{MS}+\mathrm{BAP}+\mathrm{IAA}(0.5 \mathrm{mg} / \mathrm{L}$ each $)$ & $16.3 \mathrm{~d}(0.60)$ & $1.05(0.23)$ & $4.0 \mathrm{~d}(0.08)$ \\
$1 / 2 \mathrm{MS}+\mathrm{KN}+\mathrm{IAA}(0.5 \mathrm{mg} / \mathrm{L}$ each $)$ & $26.05 \mathrm{a}(0.93)$ & $2.66 \mathrm{a}(0.48)$ & $7.9 \mathrm{a}(0.150)$ \\
$1 / 4 \mathrm{MS}$ & $16.8 \mathrm{c}(0.67)$ & $1.3 \mathrm{~b}(0.48)$ & $4.59 \mathrm{c}(0.26)$ \\
$1 / 4 \mathrm{MS}+\mathrm{IAA}(0.5 \mathrm{mg} / \mathrm{L})$ & $9.50 \mathrm{j}(0.51)$ & $1.0 \mathrm{c}(0)$ & $2.5 \mathrm{i}(0.11)$ \\
$1 / 4 \mathrm{MS}+\mathrm{BAP}(0.5 \mathrm{mg} / \mathrm{L})$ & $11.2 \mathrm{~h}(0.42)$ & $1.0 \mathrm{c}(0)$ & $3.06 \mathrm{~g}(0.10)$ \\
$1 / 4 \mathrm{MS}+\mathrm{KN}(0.5 \mathrm{mg} / \mathrm{L})$ & $8.4 \mathrm{k}(0.51)$ & $1.0 \mathrm{c}(0)$ & $2.4 \mathrm{j}(0.12)$ \\
$1 / 4 \mathrm{MS}+\mathrm{BAP}+\mathrm{IAA}(0.5 \mathrm{mg} / \mathrm{L}$ each $)$ & $10.6 \mathrm{i}(0.50)$ & $1.0 \mathrm{c}(0)$ & $2.9 \mathrm{~h}(0.11)$ \\
$1 / 4 \mathrm{MS}+\mathrm{KN}+\mathrm{IAA}(0.5 \mathrm{mg} / \mathrm{L}$ each $)$ & $13.1 \mathrm{f}(\mathrm{o} .38)$ & $1.0(0.52)$ & $3.5 \mathrm{e}(0.13)$ \\
\hline
\end{tabular}

*Means followed by a different superscript in each column are significantly $(\mathrm{P}<0.05)$ different from each other using DMRT. Numbers in brackets indicate standard deviation (SD).

Table 4. Effect of different carbon sources on shoot multiplication in $N$. ramosissimum.

\begin{tabular}{|llll|}
\hline Carbon source* & $\begin{array}{c}\text { Mean leaf } \\
\text { number } \\
\text { (SD) }\end{array}$ & $\begin{array}{c}\text { Mean shoot } \\
\text { number } \\
\text { (SD) }\end{array}$ & $\begin{array}{c}\text { Mean shoot } \\
\text { length } \\
(\mathbf{c m})(\text { SD) }\end{array}$ \\
Table sugar 3\% & $19.38^{\mathrm{b}}(1.8)$ & $1.38^{\mathrm{b}}(0.50)$ & $5.34^{\mathrm{b}}(0.07)$ \\
Fructose 1\% & $14.88^{\mathrm{d}}(1.90)$ & $1.05^{\mathrm{c}}(0.23)$ & $3.90^{\mathrm{e}}(0.07)$ \\
Fructose 3\% & $14.22^{\mathrm{c}}(0.54)$ & $1.05(0)$ & $3.90^{\mathrm{c}}(0.07)$ \\
Fructose 5\% & $11.16^{\mathrm{h}}(1.2)$ & $1.0^{\mathrm{c}}(\mathrm{o})$ & $3.12^{\mathrm{h}}(0.12)$ \\
Sucrose 1\% & $16.88^{\mathrm{c}}(0.67)$ & $1.33^{\mathrm{b}}(0.48)$ & $4.6^{\mathrm{c}}(0.10)$ \\
Sucrose 3\% & $12.33^{\mathrm{g}}(0.48)$ & $1.0^{\mathrm{c}}(0)$ & $3.29^{\mathrm{g}}(0.11)$ \\
Sucrose 5\% & $11.55^{\mathrm{h}}(0.61)$ & $1.05^{\mathrm{c}}(0.23)$ & $3.03^{\mathrm{i}}(0.07)$ \\
Maltose 1\% & $11.22^{\mathrm{h}}(0.42)$ & $1.0^{\mathrm{c}}(0)$ & $3.17^{\mathrm{h}}(0.05)$ \\
Maltose 3\% & $10.6^{1 \mathrm{i}}(0.50)$ & $1.0^{\mathrm{c}}(0)$ & $2.92^{\mathrm{j}}(0.08)$ \\
Maltose 5\% & $9.5^{\mathrm{j}}(0.51)$ & $1.0^{\mathrm{c}}(0)$ & $2.6^{\mathrm{k}}(0.07)$ \\
Dextrose 1\% & $26.05^{\mathrm{a}}(0.93)$ & $2.6^{\mathrm{a}}(0.48)$ & $7.9^{\mathrm{a}}(0.06)$ \\
Dextrose 3\% & $16.38^{\mathrm{c}}(0.60)$ & $1.05^{\mathrm{c}}(0.23)$ & $4.2^{\mathrm{d}}(0.08)$ \\
Dextrose 5\% & $8.44^{\mathrm{k}}(0.51)$ & $1.0^{\mathrm{c}}(0)$ & $2.48^{\mathrm{b}}(0.03)$ \\
\hline
\end{tabular}

*Pre-standardized half-strength MS medium supplemented with $\mathrm{KN}+\mathrm{IAA}(0.5 \mathrm{mg} / \mathrm{L}$ each); Means followed by a different superscript in each column are significantly $(P<0.05)$ different from each other using DMRT. Numbers in brackets indicate standard deviation (SD). 
Table 5. Effect of auxins on root induction in regenerated shoots of N. ramosissimum.

\begin{tabular}{|lclll|}
\hline Auxin* & $\begin{array}{c}\text { Conc. } \\
(\mathbf{m g} / \mathbf{L})\end{array}$ & $\begin{array}{c}\text { Mean root } \\
\text { number (SD) }\end{array}$ & $\begin{array}{c}\text { Mean root } \\
\text { length }(\mathbf{c m}) \\
\text { IAA }\end{array}$ & $\begin{array}{c}\text { Rooting } \\
(\%) 0\end{array}$ \\
& 0.5 & $8.33^{\mathrm{a}}(0.50)$ & $4.06^{\mathrm{a}}(0.32)$ & $87.0^{\mathrm{a}}(0.21)$ \\
& 1.0 & $6.11^{\mathrm{b}}(0.60)$ & $1.67^{\mathrm{b}}(0.25)$ & $74.5^{\mathrm{b}}(0.09)$ \\
& 1.5 & $4.440^{\mathrm{c}}(0.52)$ & $1.68^{\mathrm{b}}(0.25)$ & $62.8^{\mathrm{c}}(0.11)$ \\
& 2.0 & $3.55^{\mathrm{d}}(0.52)$ & $1.31^{\mathrm{c}}(0.16)$ & $55.2^{\mathrm{d}}(0.24)$ \\
& 2.5 & $3.22^{\mathrm{d}}(0.66)$ & $1.58^{\mathrm{b}}(0.31)$ & $47.10^{\mathrm{e}}(0.07)$ \\
& 3.0 & $2.55^{\mathrm{e}}(0.52)$ & $1.78^{\mathrm{b}}(0.19)$ & $24.6^{\mathrm{f}}(0.14)$ \\
& 3.5 & $2.66^{\mathrm{e}}(0.50)$ & $1.02^{\mathrm{d}}(0.22)$ & $14.4^{\mathrm{g}}(0.31)$ \\
$\mathbf{I B A}$ & 0.5 & $2.66^{\mathrm{bc}}(0.50)$ & $1.30^{\mathrm{c}}(0)$ & $67.0^{\mathrm{a}}(0.11)$ \\
& 1.0 & $2.60^{4}(0.52)$ & $1.20^{\mathrm{e}}(0)$ & $54.6^{\mathrm{b}}(0.23)$ \\
& 1.5 & $2.77^{\mathrm{bc}}(0.44)$ & $1.30^{\mathrm{c}}(0)$ & $37.2^{\mathrm{c}}(0.17)$ \\
& 2.0 & $3.0^{\mathrm{b}}(0)$ & $1.23^{\mathrm{d}}(0.05)$ & $26.30^{\mathrm{d}}(0.24)$ \\
& 2.5 & $3.88^{\mathrm{a}}(0.33)$ & $1.50^{\mathrm{b}}(0)$ & $26.12^{\mathrm{e}}(0.08)$ \\
& 3.0 & $3.77^{\mathrm{a}}(0.44)$ & $1.62^{\mathrm{a}}(0.04)$ & $18.09^{\mathrm{f}}(0.13)$ \\
& 3.5 & $2.11^{\mathrm{d}}(0.33)$ & $1.0^{\mathrm{f}}(0)$ & $11.10^{\mathrm{g}}(0.22)$ \\
\hline
\end{tabular}

*Pre-standardized half-strength MS Medium with dextrose (1\%); Rooting \% = several rooted plantlets/total number of explants x 100; Means followed by a different superscript in each column are significantly $(P<0.05)$ different from each other using DMRT. Numbers in brackets indicate standard deviation (SD).

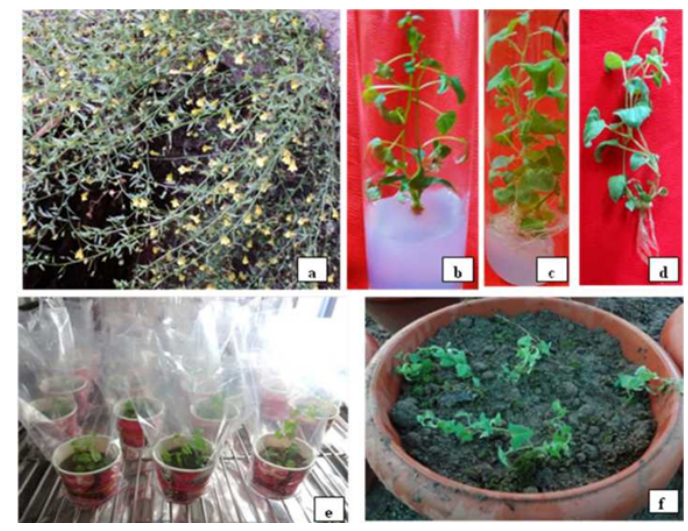

Fig. 2: Regeneration protocol established for N. ramosissimum: (a) Plants growing in natural habitat, (b) In vitro regenerated shoot on half-strength MS medium fortified with $\mathrm{KN}+\mathrm{IAA}(0.5$ $\mathrm{mg} / \mathrm{L}$ each), (c,d) In vitro rooted of micro-shoots, (e) Hardening and acclimatization of rooted plantlets, (f) Acclimatized plantlets to ex vitro conditions. 
arvensis (Phatak \& Heble, 2002). The ultimate micropropagation depends on transferring plants out of the in vitro conditions with high survival rates. In our study, a $95 \%$ survival rate of transferred plantlets to field beds could be achieved (Figure 2ef.). Greenhouse and field conditions have a considerably high level of light, less relative humidity, temperature variations, and septic environment, which can causestress to in vitro regenerated plantletswhen shifted from lab to land (Hazarika, 2003). Plants undergo certain adaptive reactions to adapt to the changing environmental conditions to facilitate their survival (Kruzhilin et al., 2018). Thus, before shifting the in vitro regenerated plantlets to field conditions, a proper acclimatization process is required to ensure that a sufficient number of plants survive and grow healthily when transferred to field conditions.

\section{Conclusion}

An efficient plant regeneration protocol for Nanorrhinum ramosissimum was established in the current study. MS medium fortified with $\mathrm{KN}$ and IAA $(0.5$ $\mathrm{mg} / \mathrm{L}$ each) supplemented with dextrose $(1 \%)$ as a carbon source resulted as the optimized medium for shoot multiplication. In comparison, rooted plantlets could be generated on a medium containing only IAA $(0.5 \mathrm{mg} / \mathrm{L})$. The protocol can serve as a productive conservation strategy as well as a method for the rapid micropropagation of this medicinally important herb.

\section{References}

Abu-Romman, S.M.; Al-Hadid, K.A. \& Arabiyyat, A.R. (2015). Kinetin is the most effective cytokinin on shoot multiplication from cucumber. Journal of Agricultural Science, 7(10): 159-165.

Ahmad, M.; Qureshi, R.; Arshad, M.; Khan, M.A. \& Zafar, M. (2009). Traditional herbal remedies are used for the treatment of diabetes from district Attock (Pakistan).
Pakistan Journal of Botany, 41: 2777-2782.

Amin, A.; Emmy, T.; Kenn, F.; Vassiliki, E.; Sandra, A. et al. (2017). in vitro and in silico antidiabetic and antimicrobial evaluation of constituents from Kickxia ramosissima (Nanorrhinum ramosissimum) Frontiers in Pharmacology, 8: 232.

Babaei, N.; Abdullah, P.; Ashikin, N.; Saleh, G. \& Lee Abdullah, T. (2014).An efficient in vitro plantlet regeneration from shoot tip cultures of Curculigo latifolia, a medicinal plant. The Scientific World Journal, https://doi. org/10.1155/2014/275028.

Bhandari, C. (2006). Vanousadhi Chandrodaya (An encyclopedia of Indian Botanis and Herbs), Varanasi: Chaukhamba Sanskrut Sansthan. Pp.117.

Bhojwani, S.S. \& Razdan, M.K. (1996). Plant tissue culture: Theory and practice, a revised edition. Studies in Plant Science. Elsevier, Amsterdam.

Diaz-Perez, J.C.; Shackel, K.A., \& Sutter, E.G. (1995). Effects of in vitro formed roots and acclimatization on water status and gas exchange of tissue cultured apple shoots. Journal of the American Society for Horticultural Science, 120(3): 435-440.

Dixon, R.A \& Gonzales, R.A. (1994). Plant Cell Culture: A Practical Approach, 2nd Ed., Oxford University Press, Oxford.

Flowers of India. (2020) Nanorrhinum ramosissimum. Retrieved from https://www. flowersofindia.net/catalog/slides/Indian $\% 20$ Toadflax.html.

Gamborg, O.L.; Murashige, T.; Thorpe, T.A., \& Vasil, I.K. (1976).Plant tissue culture media. In Vitro. Pp.12. 
Gaspar, T.; Kevers, C.; Penel, C.; Greppin, H.; Reid, D.M., et al. (1996). Plant hormones and plant growth regulators in plant tissue culture. In Vitro Cellular \& Developmental Biology - Plant, 32(4): 272-289.

Hazarika, B.N. (2003). Acclimatization of tissue-cultured plants. Current Science, 85(12): 1704-1712.

Jain, N.; Bairu, M.W.; Stirk, W.A \& Van Staden, J. (2008). The effect of medium, carbon source, and explants on regeneration and control of shoot-tip necrosis in Harpagophytum procumbens. South African Journal of Botany, 75: 117-121.

Jan, S \& Khan, M.R. (2016).Antipyretic, analgesic, and anti-inflammatory effects of Kickxia ramosissima. Journal of Ethnopharmacology, 182: 90-100.

Koch, K. (1996). Carbohydrate- modulated gene expression in plants. Annual Review of Plant Biology, 47(1): 509-540.

Kritikar, K.R. \& Basu, B.D. (2005). Indian medicinal plants, $2^{\text {nd }}$ Ed., International Book Distributors, India.

Kruzhilin, S.N.; Taran, S.S.; Semenyutina, A.V. \& Matvienko, E.Y. (2018). Growth peculiarities and age dynamics of Quercus robur L. formation in steppe region conditions. Kuwait Journal of Science, 45(4): 52-58.

Madhulatha, P.; Anbalagan, M.; Jayachandran, S. \& Sakthivel, N. (2004). Influence of liquid pulse treatment with growth regulators on in vitro propagation of banana (Musa spp. AAA). Plant Cell, Tissue and Organ Culture, 76(2): 189-192.

Mallubhotla, S.; Ahuja, A.; Kumar, A.; Sharma, R.D.; Verma, V. et al. (2008). Field performance, RAPD analysis, and withanolide profiling of micropropagated plants of WSR-an elite cultivar of Indian
Ginseng (Withania somnifera L. Dunal). Acta Horticulturae, 865:199-207.

Mohamed, S.S.; Kolar, A.B.; Malayaman, V. \& Basha, M.G. (2019). Rapid in vitro multiplication and plant regeneration from shoot tip explants of Ammannia baccifera L.: An important medicinal plant. Journal of Pharmacognosy and Phytochemistry, 8: 837-841.

Murashige, T. \& Skoog, F. (1962). A revised medium for rapid growth and bioassays with tobacco tissue culture. Physiologia Plantarum, 15: 473-497.

Neto, D.P.V.B. \& Otoni, W.C. (2003). Carbon sources and their osmotic potential in plant tissue culture: Does it matter? Scientia Horticulturae, 97(3-4): 193-202.

Ngomuo, M.; Mneney E. \& Ndakidemi, P. (2013). The effects of auxins and cytokinin on growth and development of (Musa sp.) var. "Yangambi" explants in tissue culture. American Journal of Plant Sciences, 4(11): 2174

North, J.; Ndakidemi, P. \& Laubscher, C. (2012). Effects of antioxidants, plant growth regulators, and wounding on phenolic compound excretion during micropropagation of Strelitzia reginae. International Journal of Physical Sciences, 7(4): 638-646.

Overvoorde, P.; Fukaki H. \& Overvoorde, P.; Fukaki H. \& Beeckman, T. (2010). Auxin control of root development. Cold Spring Harbor Perspectives in Biology, 2: a001537.

Pandya, P.; Acharya, R.; Shukla, V.J.; Kalyani, R. \& Khanpara, K. (2013). Physico phyto-chemical evaluation of the root of Kanoti (Linaria ramosissima Wall. Janch.), Ayurpharm International Journal of Ayurveda \& Allied Sciences, 2(9): 259-264. 
Phatak, S.V. \& Heble, M.R. (2002). Organogenesis and terpenoid synthesis in Mentha arvensis. Fitoterapia, 73: 32-39.

Pullaiah, T. \& Naidu, K. (2003). Antidiabetic plants in India and herbal-based antidiabetic research. Regency Publications, India.

Shekhawat, M.S.; Kannan, N.; Manokari, M. \& Ravindran, C.P. (2015). In vitro regeneration of shoots and ex vitro rooting of an important medicinal plant Passiflora foetida L. through nodal segment cultures. Journal of Genetic Engineering and Biotechnology, 13: 209-214.

Tetsumura, T.; Matsumoto, Y.;Sato, M.; Honsho, C.; Yamashita, K. et al. (2008). Evaluation of basal media for micropropagation of four high bush blueberry cultivars. Scientia Horticulturae, 119(1): 72-74.

The Plant List. Nanorrhinum ramosissimum (Wall.) Betsche. Retrieved from www. theplantlist.org/tpl/record/kew-2335109.

Thomson, M. \& Thorpe, T.A. (1987). Metabolic and non-metabolic roles of carbohydrates, In Bong, J.M. \& Durzan, D.J. (Ed.). Cell and tissue culture in forestry, Pp.89-112. Martinus Nijhoff, Dardrecht.

White, A.R. (1963). The cultivation of animal and plant cells, $2^{\text {nd }} \mathrm{Ed}$. The Ronald Press, New York.

$\begin{array}{lr}\text { Submitted: } & 30 / 01 / 2020 \\ \text { Revised: } & 11 / 06 / 2020 \\ \text { Accepted: } & 20 / 06 / 2020 \\ \text { DOI: } & 10.48129 / \text { kjs.v48i3.9100 }\end{array}$

